This item was submitted to Loughborough's Research Repository by the author.

Items in Figshare are protected by copyright, with all rights reserved, unless otherwise indicated.

\title{
Leaf-litter stoichiometry is affected by streamwater phosphorus concentrations and litter type
}

\section{PLEASE CITE THE PUBLISHED VERSION}

https://doi.org/10.1899/12-215.1

\section{PUBLISHER}

(C) The Society for Freshwater Science

\section{VERSION}

VoR (Version of Record)

\section{PUBLISHER STATEMENT}

This work is made available according to the conditions of the Creative Commons Attribution-NonCommercialNoDerivatives 4.0 International (CC BY-NC-ND 4.0) licence. Full details of this licence are available at: https://creativecommons.org/licenses/by-nc-nd/4.0/

\section{LICENCE}

CC BY-NC-ND 4.0

\section{REPOSITORY RECORD}

Scott, Erin E., Clay Prater, Eric J. Norman, Bryant C. Baker, Michelle A. Evans-White, and J. Thad Scott. 2019. "Leaf-litter Stoichiometry Is Affected by Streamwater Phosphorus Concentrations and Litter Type". figshare. https://hdl.handle.net/2134/28331. 


\title{
Leaf-litter stoichiometry is affected by streamwater phosphorus concentrations and litter type
}

\author{
Erin E. Scott ${ }^{1,3}$, Clay Prater ${ }^{2,4}$, Eric Norman ${ }^{1,5}$, Bryant C. Baker ${ }^{1,6}$, Michelle \\ Evans-White ${ }^{2,7}$, AND J. Thad Scott ${ }^{1,8}$ \\ ${ }^{1}$ Department of Crop, Soil, and Environmental Sciences, 115 Plant Sciences Building, University of \\ Arkansas, Fayetteville, Arkansas 72701 USA \\ ${ }^{2}$ Department of Biological Sciences, 601 Science and Engineering Building, University of Arkansas, \\ Fayetteville, Arkansas 72701 USA
}

\begin{abstract}
The stoichiometric ratios of organisms and their food resources can influence $C$ and nutrient dynamics in aquatic ecosystems. Several investigators have quantified linkages between nutrient enrichment and consumer stoichiometry for stream detritivores, but very few have systematically quantified the effect of $\mathrm{P}$ enrichment on leaf-litter stoichiometry. Here, we examine the potential stoichiometric changes of 2 species of leaf litter subjected to varying levels of $\mathrm{P}$ enrichment in laboratory microcosms and mixed species across a natural P gradient of streams in the Ozark Highlands Region, Arkansas, USA. Leaf-litter \% $\mathrm{P}$ content increased and C:P ratios decreased with increasing levels of $\mathrm{P}$ enrichment and with increasing lability of the leaf species. In the laboratory study, C:P of maple and oak leaves in the control treatment was $\sim 2500$, whereas this ratio decreased to 500 and 1000 in the high-P treatments, respectively. Total P (TP) was inversely related to leaf-litter C:P along the natural P gradient of streams in the Ozarks. Our results add to the growing body of information on the potential bottom-up effects of anthropogenic nutrient loading in streams and the influence of water-column nutrients and leaf quality on this response.
\end{abstract}

Key words: nutrients, phosphorus, stoichiometry, leaf litter, detritus, streams, aquatic fungi, decomposition.

Anthropogenic activities can greatly alter biogeochemical processes involving C, N, and P. Rising human populations and increasing agricultural and urban land expansion and intensity result in excess nutrient loading in many ecosystems (Carpenter et al. 1998, Alexander et al. 2008, Jarvie et al. 2010). Nutrient enrichment of lentic ecosystems has been studied extensively and can result in increased toxic algal blooms, decreased $\mathrm{O}_{2}$ concentrations, increased turbidity, and declines in species diversity, among other effects (Smith 2003, Dodds et al. 2009). Effects on lotic ecosystems are less well understood (Smith et al. 1999, Dodds 2006, 2007). A growing body of research

\footnotetext{
${ }^{3}$ E-mail addresses: ees003@uark.edu

4 mikelprater@trentu.ca

5 normaneric72@gmail.com

${ }^{6}$ bcbaker@uark.edu

7 mevanswh@uark.edu

${ }^{8}$ To whom correspondence should be addressed. E-mail: jts004@uark.edu
}

demonstrates that nutrient enrichment produces responses from leaf-litter-associated heterotrophic microbial assemblages (Greenwood and Rosemond 2005, Dodds 2007, Hill et al. 2011), but more attention to quantitative changes in litter quality is needed.

Nutrient enrichment of heterotrophic systems can increase decomposition and decrease C standing stock (Suberkropp et al. 2010). Low-order streams often are detritus-based systems where the vast majority of available energy comes from allochthonous organic matter (Fisher and Likens 1973, Vannote et al. 1980). Leaf litter typically has very poor initial quality (e.g., high $\mathrm{C}$, low $\mathrm{N}$ and $\mathrm{P}$ ) because of its complex $C$ structure and presenescent resorption of nutrients (Aerts 1996, Kobe et al. 2005). Microorganisms rapidly colonize leaf surfaces upon submersion of leaves in streams (Suberkropp and Klug 1974). Microbes, especially fungi, perform an essential ecosystem service in streams by transforming leaf litter into a more palatable resource for detritivores (Kaushik and Hynes 1971, Romani et al. 2006, Gessner 
et al. 2007). Aquatic fungi are capable of producing the extracellular enzymes required to degrade recalcitrant leaf polymers like lignin and, therefore, dominate early successional stages of leaf-litter colonization (Suberkropp and Klug 1976, Gessner and Chauvet 1994, Romani et al. 2006). Fungi and bacteria obtain $\mathrm{C}$ and nutrients from the leaves directly and are capable of obtaining $\mathrm{N}$ and $\mathrm{P}$ from the water column (Suberkropp and Chauvet 1995, Suberkropp 1998, Findlay 2010). Therefore, heterotrophic decomposers can strongly influence watercolumn nutrient concentrations and biogeochemical processes.

Differences in leaf-litter decomposition rates have been reported across natural nutrient gradients (Suberkropp and Chauvet 1995, Rosemond et al. 2002), paired whole-stream-enrichment experiments (Elwood 1981, Gulis and Suberkropp 2003, Greenwood et al. 2007), nutrient-diffusing substrate experiments (Robinson and Gessner 2000), and in microecosystem flow-through studies (Howarth and Fisher 1976). Changes in leaf-litter decomposition rates often are attributed to enhanced heterotrophic activity in response to nutrient enrichment. Increases in $\mathrm{N}$ and $\mathrm{P}$ availability can stimulate microbial biomass (Rosemond et al. 2002, Benstead et al. 2005, Suberkropp et al. 2010) and respiration rates (Elwood et al. 1981, Stelzer et al. 2003, Suberkropp et al. 2010) associated with leaf litter. However, relatively few investigators have demonstrated how increased nutrient availability might affect leaf-litter quality (defined by nutrient content and stoichiometric ratios). Elwood et al. (1981) enriched an oligotrophic stream (background soluble reactive $\mathrm{P}[\mathrm{SRP}]$ and dissolved inorganic $\mathrm{N}$ [DIN] were 4 and $35 \mu \mathrm{g} / \mathrm{L}$, respectively) with either 60 or $450 \mu \mathrm{g} / \mathrm{L}$ SRP and measured an $83 \%$ increase in $P$ content of red oak (Quercus rubra) leaves in the enriched reaches compared to the control. Cross et al. (2003) and Small and Pringle (2010) reported increases in \%P and subsequent decreases in C:P of leaf litter in streams with greater $\mathrm{N}$ or $\mathrm{P}$ availability, but more data are needed to understand the magnitude of change caused by nutrient enrichment in diverse stream ecosystems. Understanding the quantitative link between water-column $\mathrm{P}$ availability and leaflitter stoichiometry is important for predicting ecosystem changes caused by anthropogenic nutrient enrichment of streams.

P enrichment can alter leaf-litter P content and C:P, leading to decreased resource-consumer imbalance (Cross et al. 2003). This difference in elemental composition between resource and consumer can limit consumer productivity and provides important selection pressure to promote species diversity in streams (Dodds et al. 2009, Evans-White et al. 2009). Some investigators have explored the effects of variable water-column nutrient availability on leaflitter-associated microbial biomass and decomposition (Gulis and Suberkropp 2003, Baldy et al. 2007) and of detrital stoichiometry on the trophic response of invertebrates (Hladyz et al. 2009, Small et al. 2011), but broad assumptions often are made concerning the chemical alterations in the basal food resources. Specifically, many investigators have qualitatively described an increase in litter P content inferred from greater microbial biomass, but few have explicitly quantified changes in litter stoichiometry (Abelho and Graça 2006, Webster et al. 2009, Cheever et al. 2012). Moreover, much experimental manipulation has been done with $\mathrm{N}$ or $\mathrm{N}+\mathrm{P}$, but very few studies have been focused on $\mathrm{P}$ explicitly. This focus is an important avenue for research because $\mathrm{P}$ limitation is common in forested streams (Elwood et al. 1981, Chadwick and Huryn 2005, Ardón and Pringle 2007).

The objective of our study was to explore the effect of $\mathrm{P}$ enrichment on leaf-litter stoichiometry with data collected in the laboratory and the field. Our goals were to: 1) quantify the effect of $P$ exposure time and concentration on leaf-litter chemistry and 2) explore response differences between post oak (Quercus stellata Wangenh.) and sugar maple (Acer saccharum Marsh.). These species are common in many deciduous forests throughout the USA and are among the dominant species in our study region. Post oak and sugar maple have inherently different chemical properties (specifically in structural C compounds). Leaf litter is primarily a pulsed organic $C$ input and time-series changes to quality might variably affect different shredder taxa. We predicted that leaf C:P would decrease through time after leaves enter stream water and with increasing levels of $\mathrm{P}$ enrichment for both leaf types. Given similar initial $\mathrm{N}$ and $\mathrm{P}$ content in maple and oak leaves but greater lignin content in oak, we predicted that $\mathrm{P}$ enrichment would elicit a greater response from microorganisms on labile maple leaves than on the more recalcitrant oak leaves because microorganisms on oak leaves would be more constrained by $\mathrm{C}$ availability. We also tested for a correlation between C:P of mixed leaf species and streamwater TP along a natural $\mathrm{P}$ gradient in streams. We predicted that C:P of mixed leaf species would decrease with increasing watercolumn $\mathrm{P}$ availability across a range of natural stream $\mathrm{P}$. We tested these predictions by manipulating $\mathrm{P}$ in a laboratory experiment and with a field survey of streams in the Ozark Highlands Region, Arkansas, USA. 


\section{Methods}

\section{Laboratory experiment}

We used a laboratory microcosm experiment with a factorial design to examine the effect of leaf-litter species (sugar maple and post oak) and increased soluble reactive $\mathrm{P}$ (SRP) concentration (additions of 0 , 50 , or $500 \mu \mathrm{g}$ SRP/L) on litter stoichiometry. We used 3 replicate microcosms for each $\mathrm{P}$ treatment and incubated both leaf types, in different leaf bags, in each microcosm. We sampled over time (day 0, 5, 8, $13,20,28,36,43,59,72,95,115$, and 139) for litter $C$ and $\mathrm{P}$ content.

We collected maple and oak leaves in the southwestern Ozark Highlands shortly after abscission in November 2010, dried them at ambient temperatures for $2 \mathrm{wk}$, cut them into 13.5 -mm-diameter leaf disks with major veins avoided, and stored them at $40^{\circ} \mathrm{C}$ for 2 wk until the start of the experiment. We put $\sim 40$ disks of the same species in each of nine 10-mm mesh bags.

We filled 1-L microcosms with $750 \mathrm{~mL}$ of unfiltered stream water from Jones Creek, a $3^{\text {rd }}$-order stream near Winfrey, Arkansas, that has low concentrations of SRP $(<6 \mu \mathrm{g} / \mathrm{L})$ and moderate concentrations of $\mathrm{NO}_{3}{ }^{-}\left(\mathrm{NO}_{3}-\mathrm{N}=345 \pm 32 \mu \mathrm{g} / \mathrm{L}\right)$. Therefore, with increasing P enrichment, ambient molar N:P was 130 , 14 , and 1.5 for the control, low-P, and high-P treatments, respectively. In streams polluted with $\mathrm{P}$, particulate $\mathrm{P}$ can contribute a large proportion of the available $P$ pool, but streams receiving large volumes of treated wastewater effluent can have very elevated SRP. Therefore, we used a high SRP enrichment $(500 \mu \mathrm{g} / \mathrm{L})$ to simulate highly enriched P conditions. We placed 2 leaf bags, one for each leaf species, in each microcosm. We aerated all microcosms constantly and flushed them on each sampling day with fresh, unfiltered stream water plus appropriate SRP amendments. Between each of the last 3 sampling days, we added tap water $(\sim 200 \mathrm{~mL}$ maximum) to maintain a constant volume in the microcosms. Tap water concentrations for SRP and $\mathrm{NH}_{4}-\mathrm{N}$ were below detection, but $\mathrm{NO}_{3}-\mathrm{N}$ was $1.3 \mathrm{mg} / \mathrm{L}$.

We collected 2 disks of each leaf species from the microcosms on each sampling day, dried them for $\sim 48 \mathrm{~h}$ at $50^{\circ} \mathrm{C}$, then froze them for later analysis of organic C (litter C) and P (litter P). We redried frozen disks for 24 to $48 \mathrm{~h}\left(50^{\circ} \mathrm{C}\right)$ and analyzed $\mathrm{C}$ content with a Thermo Flash 2000 Organic Elemental Analyzer (Thermo Fisher Scientific, Delft, The Netherlands). We measured litter $\mathrm{P}$ by combusting disks at $550^{\circ} \mathrm{C}$ and then oxidizing $\mathrm{P}$ by persulfate digestion before analyzing colorimetrically with the ascorbic acid method (APHA 2007). All ratios are reported in molar units.
Natural P gradient of streams

We collected water and leaf-litter samples between 20 March and 11 April $2009(n=6)$ and $2010(n=8)$ from low-order headwater streams in the Ozark Highlands region of northwestern Arkansas. Land use in these watersheds was predominantly forest $(34-92 \%$, mean $=71 \%)$ and pasture $(4-52 \%$, mean $=$ $20 \%)$. Mean stream width and depth were $7.5 \mathrm{~m}$ (2.0$23.3 \mathrm{~m})$ and $0.26 \mathrm{~m}(0.04-1.50 \mathrm{~m})$, respectively. Stream substrata were primarily gravel, and streams had riffle-pool channel morphology (Brussock et al. 1985). Preliminary data suggested that these streams represented a gradient in total $\mathrm{P}(\mathrm{TP})$ concentration.

We collected 2 composite water samples, 1 filtered (glass-fiber filter, $1-\mu \mathrm{m}$ mesh) and 1 unfiltered, from the thalweg of a well mixed region of each stream before sampling detritus. We kept samples on ice, returned them to the laboratory, and froze them until analysis. We analyzed filtered water samples for $\mathrm{NO}_{3}-$ $\mathrm{N}$ with the Cd-reduction method and $\mathrm{NH}_{4}-\mathrm{N}$ with the sodium hypochlorite method on a Lachat QuikChem 8500 using the QuickChem method 10-107-04-1-B and C (Lachat Instruments, Hach Company, Loveland, Colorado). We analyzed TP in unfiltered samples with the ascorbic acid method on a Genesys 10vis spectrophotometer (Thermo Scientific, Delft, The Netherlands) following persulfate digestion (APHA 2007). We analyzed TP because it is a better predictor than soluble reactive $\mathrm{P}$ of nutrient supply to organisms in noneutrophic systems (Dodds 2003).

We collected leaves with kick nets in riffles and pools of each stream without regard to taxon. The sampling area for each kick was $0.2 \mathrm{~m}^{2}$ and we collected 10 kicks throughout each site (from along the stream edge, thalweg, and top and bottom of the reach). We rinsed the leaves with stream water, placed them in paper sacks and kept them in a cooler on ice until we reached the laboratory where we dried them immediately $\left(<50^{\circ} \mathrm{C}, 24-48 \mathrm{~h}\right)$. We ground dried leaf-litter samples to a fine powder in a Wig-L-Bug ${ }^{\circledR}$ grinder (Crescent 3110B; Rinn, Elgin, Illinois) and analyzed subsamples for litter $C$ as described above. We measured litter $\mathrm{P}$ content by combusting the material at $550^{\circ} \mathrm{C}$ and incubating the material in $1 \mathrm{~N}$ hydrochloric acid for $30 \mathrm{~min}$ at $85^{\circ} \mathrm{C}$ (Rosemond et al. 1993). Following digestion, we diluted samples to $100 \mathrm{~mL}$ and processed them with the ascorbic acid method (APHA 2007).

\section{Statistical analyses}

We used Michaelis-Menten kinetic models (SigmaPlot version 12.0; Systat Software, San Jose, California) to evaluate the stoichiometric saturation of $\mathrm{P}$ in litter 
$\left(\mathrm{C}: \mathrm{P}_{\text {sat }}\right)$ and the time required to elicit such a response in the enrichment experiment. This approach allowed us to estimate the saturating P:C (inverted for positive response with time) ratio and the amount of time required to reach saturation. C:P in the control treatments for both maple and oak did not change through time, so we used C:P values from all sampling days to calculate respective means. We used 1-way analysis of variance (ANOVA) to quantify how C:P saturation and time-to-saturation data were influenced by leaf species and enrichment concentration. We analyzed leaf N:P and \%C data with a 1-way ANOVA of all data collected after day 8 (before day 8 , chemistry within a treatment was too variable and $\mathrm{N}: \mathrm{P}$ did not significantly change through time). We used PROC GLM in SAS (version 9.1; SAS institute, Cary, North Carolina) to conduct the ANOVAs and the REGWQ multiple range analysis to test for differences among individual treatments when the omnibus $F$ test was significant at $\alpha=0.05$. We used linear regression analysis (SigmaPlot 12.0) to analyze the relationship between streamwater TP and leaflitter C:P across the natural P gradient of streams.

\section{Results}

\section{Laboratory experiment}

Leaf-litter \% increased through time in the lowand high-P treatments, and differed across $\mathrm{P}$ treatments, from 0.05 to 0.25 and 0.05 to 0.15 for maple and oak, respectively (Fig. 1A, B). This increase led to a subsequent decrease in leaf C:P from 2000 to 500 and from 2500 to 1000 for maple and oak, respectively (Fig. 2A, B). C: $\mathrm{P}_{\text {sat }}$ differed significantly across Penrichment levels and leaf species (Table 1). For all but the control treatments, maple-leaf $C: P_{\text {sat }}$ decreased significantly more than oak-leaf $C: P_{\text {sat }}$ for a given $\mathrm{P}$ concentration (Table 1). Maple-leaf $\mathrm{C}: \mathrm{P}_{\text {sat }}$ decreased to $\sim 490$ and $\sim 300$ for low-P and high-P treatments, respectively, and these values were not significantly different. Oak-leaf $\mathrm{C}: \mathrm{P}_{\text {sat }}$ decreased to $\sim 1450$ and $\sim 790$ for low-P and high-P treatments, respectively, and these values did differ significantly. High-P enrichment of oak leaves elicited a response similar to low-P enrichment of maple leaves. In the control treatments, $\mathrm{C}: \mathrm{P}$ of maple and oak leaves were similar $(C: P \approx 2550)$ and did not change through time. Maple-leaf chemistry saturated later in time than did oak-leaf chemistry ( $\sim 135$ and $30 \mathrm{~d}$, respectively). P concentration did not affect time to saturation for either species (Table 1). The change in litter C:P was primarily a result of change in $\% \mathrm{P}$ (Fig. 1A, B) rather than in \%C. Percent $C$ ranged from 42 to $51 \%$ and increased slightly through time for maple leaves
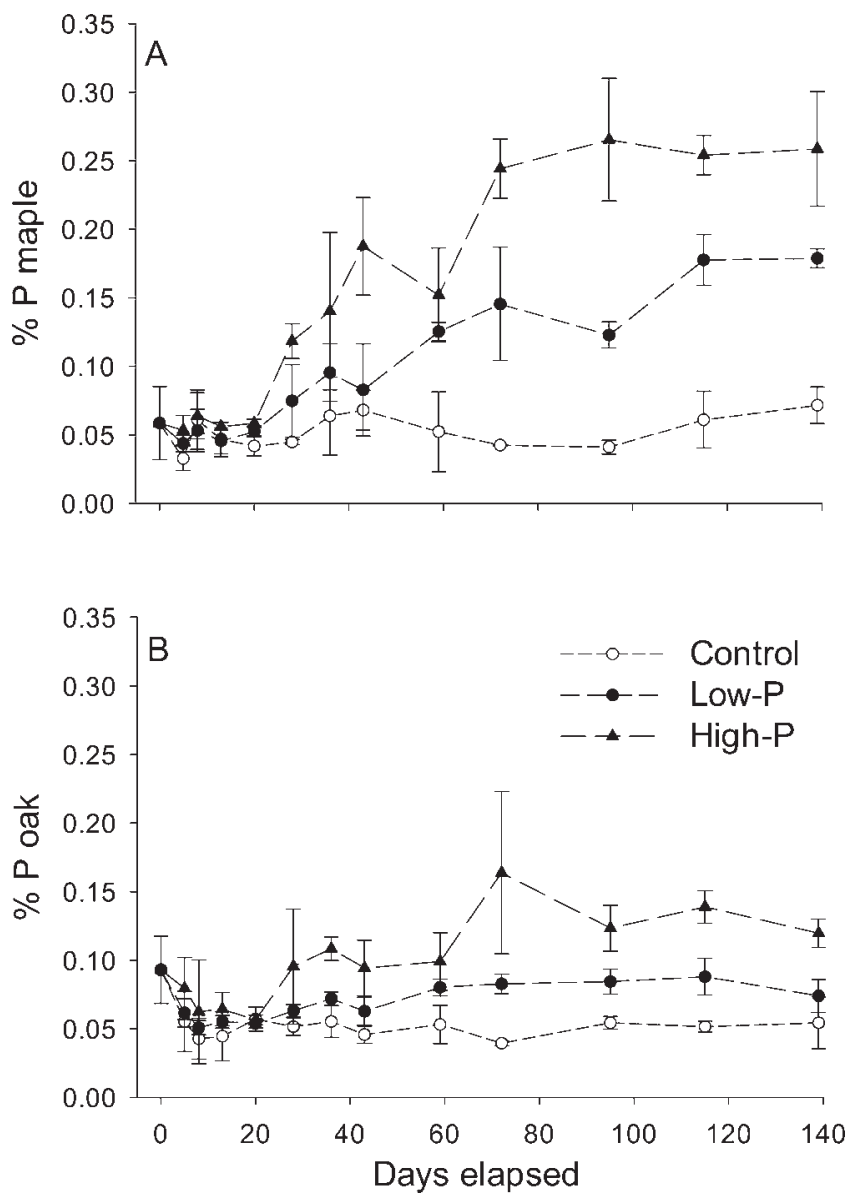

FIG. 1. Mean ( $\pm 1 \mathrm{SD}) \% \mathrm{P}$ of maple (A) and oak (B) leaf litter through time in the laboratory experiment.

$(p<0.01)$. Mean leaf-litter N:P ranged from $\sim 25$ to $\sim 70$ and was significantly related to leaf species and $\mathrm{P}$ treatment, following an almost identical statistical pattern to C:P (Table 1). Leaf-litter $\% \mathrm{~N}$ and C:N did not differ across treatments.

\section{Natural P gradient of streams and combined data}

TP concentrations ranged from 8.0 to $62.3 \mu \mathrm{g} / \mathrm{L}$ (mean $=26.4 \mu \mathrm{g} / \mathrm{L}$ ) across the natural stream $\mathrm{P}$ gradient, and leaf-litter C:P ranged from 3104 to 989 $($ mean $=2096)$ across this gradient. Streamwater TP and leaf-litter C:P (Fig. 3) were negatively linearly related in $2009\left(p<0.01, r^{2}=0.90, n=6\right), 2010(p=$ $\left.0.03, r^{2}=0.58, n=8\right)$, and when all data were combined ( $p<0.005, r^{2}=0.59$; Fig. 3). Mixed leaflitter $\% \mathrm{C}$ was similar across sites and ranged from 42 to $47 \%, \% \mathrm{~N}$ ranged from 1.0 to $1.7 \%, \% \mathrm{P}$ ranged from 0.05 to $0.11 \%, \mathrm{C}: \mathrm{N}$ ranged from 30 to 54 , and $\mathrm{N}: \mathrm{P}$ ranged from 34 to 74 . When the leaf C:P field data were plotted with the C:P saturation values from the experiment, both data sets aligned along $\mathrm{P}$ concentrations 

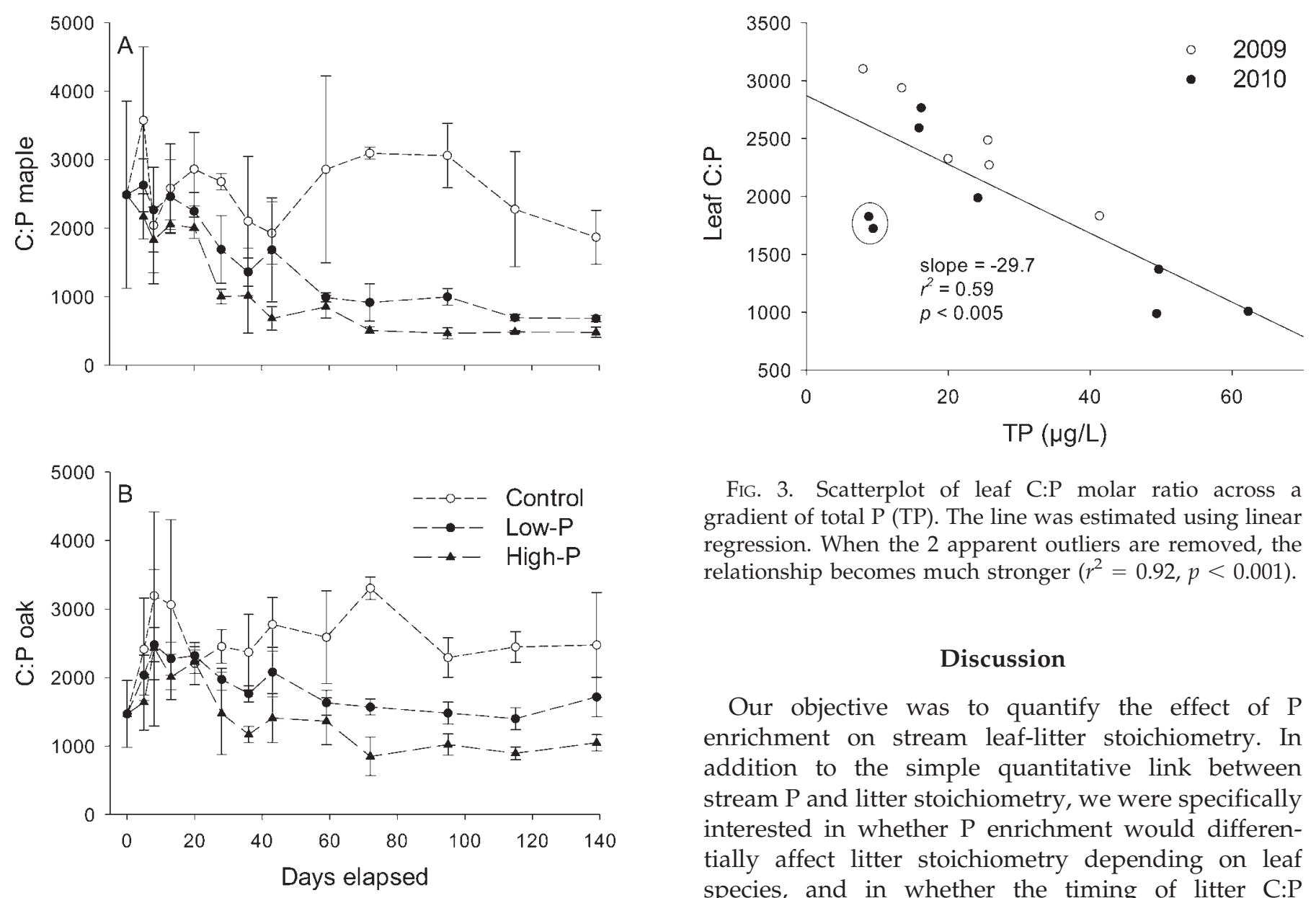

FIG. 3. Scatterplot of leaf C:P molar ratio across a gradient of total $\mathrm{P}$ (TP). The line was estimated using linear regression. When the 2 apparent outliers are removed, the relationship becomes much stronger $\left(r^{2}=0.92, p<0.001\right)$.

\section{Discussion}

Our objective was to quantify the effect of $\mathrm{P}$ enrichment on stream leaf-litter stoichiometry. In addition to the simple quantitative link between stream P and litter stoichiometry, we were specifically interested in whether P enrichment would differentially affect litter stoichiometry depending on leaf species, and in whether the timing of litter C:P saturation would vary with leaf type and P-enrichment level. Our results showed that $P$ enrichment affects C:P saturation of litter differently depending on litter type and that the timing of C:P saturation also varies with litter type. Furthermore, the response of litter $\mathrm{C}: \mathrm{P}$ to an experimental $\mathrm{P}$ gradient was similar to the correlation between mixed-leaf C:P and streamwater TP across a natural $\mathrm{P}$ gradient in streams.

TABLE 1. Mean ( \pm SD) N:P, the saturation C:P $\left(C: P_{\text {sat }}\right)$, and time to saturation and results from analyses of variance comparing effect of P concentration and leaf type on leaf-litter N:P $\left(F_{5,179}=50.4\right), \mathrm{C}: \mathrm{P}_{\text {sat }}\left(F_{5,12}=115.6, p<0.0001\right)$, and day of C:P saturation $\left(F_{3,8}=9.28, p<0.01\right)$ of leaf litter based on the Michaelis-Menten saturation models. Treatments or leaf types with the same letters are not statistically different. $R^{2}$ values indicate the strength of the Michaelis-Menten model when all replicates for each treatment were combined. An asterisk $\left(^{*}\right)$ denotes treatments that could not be modeled with a saturation curve. C:P values are means across all sampling days.

\begin{tabular}{|c|c|c|c|c|c|c|c|c|c|}
\hline \multicolumn{2}{|c|}{ Treatment } & \multirow{2}{*}{$\frac{P \text { addition }(\mu \mathrm{g} / \mathrm{L})}{0}$} & \multicolumn{2}{|c|}{$\mathrm{N}: \mathrm{P}$} & \multicolumn{2}{|l|}{$\mathrm{C}: \mathrm{P}_{\text {sat }}$} & \multicolumn{2}{|c|}{ Day of C:P $P_{\text {sat }}$} & \multirow[t]{2}{*}{ Adj. $R^{2}$} \\
\hline Maple & Control* & & $63 \pm 22$ & A & $2573 \pm 271$ & A & & & \\
\hline & Low $\mathrm{P}$ & 50 & $31 \pm 8$ & $C D$ & $489 \pm 57$ & $C D$ & $129 \pm 35$ & A & 0.77 \\
\hline & High P & 500 & $24 \pm 9$ & $\mathrm{D}$ & $298 \pm 54$ & D & $142 \pm 53$ & A & 0.80 \\
\hline \multirow{3}{*}{ Oak } & Control* & 0 & $68 \pm 19$ & A & $2542 \pm 237$ & A & & & \\
\hline & Low $\mathrm{P}$ & 50 & $44 \pm 6$ & B & $1453 \pm 95$ & B & $16 \pm 4$ & B & 0.57 \\
\hline & High $P$ & 500 & $36 \pm 10$ & $\mathrm{BC}$ & $792 \pm 116$ & C & $48 \pm 30$ & B & 0.42 \\
\hline
\end{tabular}




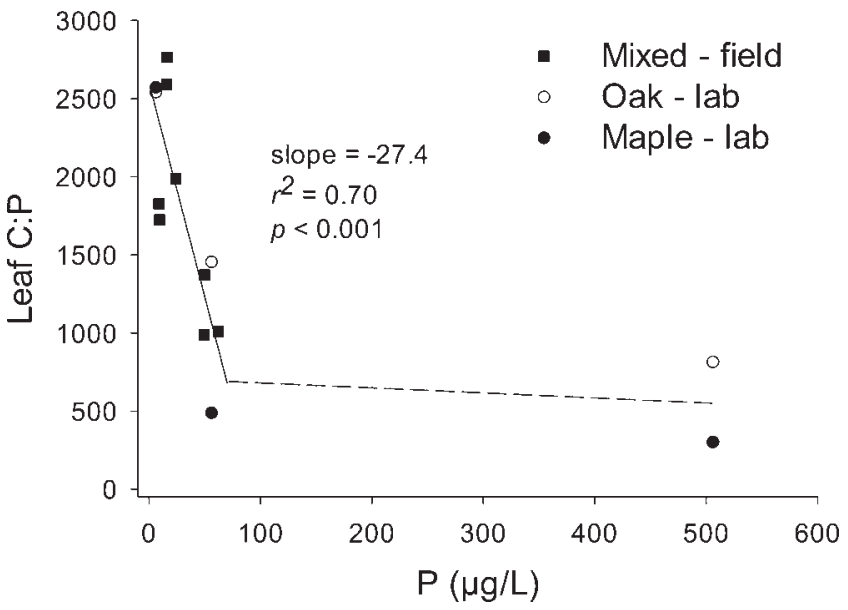

FIG. 4. Scatterplot of leaf C:P molar ratio for the field survey and laboratory experiment across a range of $\mathrm{P}$ concentrations. This figure illustrates congruence across the field and laboratory data and suggests a potential threshold in ambient $\mathrm{P}$ concentrations where a significant change in litter C:P may be elicited. A regression line was drawn from the data with $\mathrm{P}$ concentrations $<100 \mu \mathrm{g} / \mathrm{L}$ and the slope of the line was similar to that of the field data alone (Fig. 3). The dashed line represents the hypothetical saturation of $\mathrm{C}: \mathrm{P}$. Total $\mathrm{P}$ and soluble reactive $\mathrm{P}$ were used for the field survey and the laboratory experiment, respectively.

\section{Effect of P enrichment on leaf-litter stoichiometry}

Leaf-litter \%P, C:P, and N:P differed across experimental $\mathrm{P}$ treatments and among leaf species. Percent $P$ increased with experimental $P$ concentration, which led to decreases in C:P and N:P for both leaf species. Microbial activity can increase leaf-litter nutrient content as in-stream conditioning progresses (Kaushik and Hynes 1971). In undisturbed forested streams, biotic activity often is limited by $\mathrm{N}$ or $\mathrm{P}$ (Elwood et al. 1981, Hladyz et al. 2009, Hill et al. 2010). P enrichment of streams can result in increased microbial activity including enhanced production and respiration rates (Rosemond et al. 2002, Gulis and Suberkropp 2003, Greenwood et al. 2007, Suberkropp et al. 2010). Consistent with other studies, $\mathrm{P}$ content and consequent decreases in $\mathrm{C}: \mathrm{P}$ and $\mathrm{N}: \mathrm{P}$ were greater for enriched leaves than for controls, a result suggesting that microbes may have been P-limited (ambient stream molar $\mathrm{NO}_{3}-\mathrm{N}: \mathrm{SRP}$ was $\sim 130$ ).

Percent $\mathrm{P}$ of leaves exposed to high-P enrichment increased by as much as 30 and $350 \%$ for oak and maple, respectively. Other investigators have reported an $\sim 60$ to $80 \%$ increase in litter $\% \mathrm{P}$ with $\mathrm{P}$ enrichment relative to controls (Elwood et al. 1981, Cross et al. 2003). The relatively large change in maple C:P could have been a function of our experimental design, but other indicators confirm that this change may not be unreasonable. For example, the range of C:P ratios of maple from the enrichment experiment was 500 to 3500 and changed with time and treatment. The range of C:P values across the stream $\mathrm{P}$ gradient was 1000 to 3000. Stelzer et al. (2003) reported an initial \%P of $0.049 \%$ and C:P of 2412 for sugar maple leaves. These values are very close to the values that we found. Small and Pringle (2010) reported C:P values for mixed litter in tropical streams that ranged from 500 to 2000, depending on streamwater P. Similarly, Cross et al. (2003) reported mean C:P of mixed leaf litter ranging from 3000 in an enriched reach to 5000 in a reference reach. Thus, the range of C:P observed in our experimental manipulations was not unusual.

The magnitude of $\mathrm{P}$ enrichment can also influence the leaf-litter stoichiometric response. Our experimental study was intended to simulate potential extremes of $\mathrm{P}$ concentrations in streams, including those receiving treated wastewater. When we analyzed the data from the field gradient and the laboratory enrichment experiment together, we found congruence in the trend of stoichiometric change with increasing water-column TP concentration (Fig. 4). Litter exposed to the extremely high $\mathrm{P}$ concentrations $(500 \mu \mathrm{g} / \mathrm{L})$ in the manipulation experiments did not have a significantly lower C:P than litter exposed to much lower TP concentrations $(50-60 \mu \mathrm{g} / \mathrm{L})$ in the laboratory experiment and in streams. C:P values for litter exposed to these lower concentrations aligned well with one another. This result might provide evidence for a potential threshold in ambient $\mathrm{P}$ concentrations at which litter C:P may not change with higher concentrations of P. Results of other studies indicate that this threshold may occur between 25 and $50 \mu \mathrm{g} \mathrm{P/L}$ (Rosemond et al. 2002, Small and Pringle 2010). This result is important because macroinvertebrate richness responds to changes in resource quality (Evans-White et al. 2009). Further study is necessary to fill the gap between $\sim 60$ and $50 \mu \mathrm{g} / \mathrm{L}$ in the $\mathrm{P}$ concentrations that have been studied, but our results have strong potential for use in establishing nutrient criteria in streams with detritus-based food webs.

One potential limitation of our experimental design was that the microcosms lacked flow that would have constantly replenished the nutrient supply. Thus, the experimental units could have experienced an extreme drawdown of ambient nutrients that may have led to more severe nutrient limitation, especially in the control and low-P treatments. We tested this hypothesis in association with an ongoing study. We found that ambient concentrations of SRP decreased 
quickly to below detection limits after beakers were flushed, but mean water-column TP concentrations were $\sim 45$ and $65 \mu \mathrm{g} / \mathrm{L}$ in the control and low-P treatments, respectively. This result suggests that $\mathrm{P}$ turnover from the water column probably was an important $\mathrm{P}$ source to litter, which is similar to conditions often observed in streams (Dodds 2003).

\section{The role of $C$ lability in detrital stoichiometry}

Maple leaves responded differently to $P$ enrichment than did oak leaves. Maple leaves responded earlier, longer, and to a greater extent to $\mathrm{P}$ enrichment than did oak leaves. Both maple and oak leaves had significantly different $C: P_{\text {sat }}$ in the low-P treatment than in their respective controls. Maple-leaf $C: P_{\text {sat }}$ did not differ between the low- and high-P treatments, but oak-leaf $C: P_{\text {sat }}$ did (Table 1). This result suggests that an SRP concentration of $50 \mu \mathrm{g} / \mathrm{L}$ saturated microbial P uptake on maple leaves but not on oak leaves. We also found that low-P enrichment of maple leaves yielded a litter C:P similar in magnitude to that of high-P enrichment of oak leaves. Therefore, microbially mediated litter stoichiometry depends on streamwater $\mathrm{P}$ concentrations and on intrinsic qualities of the leaf species.

Fungal activity and decomposition can be regulated by inherent litter quality, such as lignin content (Gessner and Chauvet 1994, Gessner et al. 2007). Ardón and Pringle (2007) experimentally enriched low-lignin (Trema integerrima) and high-lignin (Zygia longifolia) leaf species and showed that the availability of labile $C$ can influence the stimulatory effect of $P$ enrichment. Biofilm respiration was C-limited on high-lignin Zygia, so P enrichment did not stimulate respiration. In contrast, respiration was not $\mathrm{C}$-limited on low-lignin Trema, and P enrichment did stimulate respiration. Our results indicate that the relatively labile maple leaves were more sensitive than the relatively recalcitrant oak leaves to $\mathrm{P}$ enrichment. Maple-leaf C:P was equal at low- and high-P concentrations, whereas oak-leaf C:P was different between enrichment levels. Other investigators have shown opposite effects. Greenwood et al. (2007) reported that $\mathrm{N}+\mathrm{P}$ enrichment stimulated relatively recalcitrant rhododendron leaves more than relatively labile red maple leaves. They assumed relative lability based on variation in initial leaf C:N (high for rhododendron, low for red maple). Initial $\mathrm{N}$ and $\mathrm{P}$ content of oak and maple leaves in our study were similar, but these leaf species differ in amount and types of structural C compounds, such as lignin (Melillo et al. 1982, Hladyz et al. 2009). Absolute lignin content and lignin:P are the most important predictors and drivers of leaf-litter-associated microbial activity (Gessner and Chauvet 1994, Hladyz et al. 2009), a conclusion supported by our results.

\section{Natural gradients and timing of litter conditioning}

Streamwater TP and mixed-species leaf-litter C:P were negatively correlated across a natural $\mathrm{P}$ gradient in Ozark streams. The mean leaf C:P (2087) in our field survey was similar to that of mixed leaf species in studies by Cross et al. (2003) and Evans-White et al. (2005). Our results also are consistent with those of many other studies showing an increase in \% $\mathrm{P}$ or a decrease in C:P of leaves with increasing $P$ availability in natural (Rosemond et al. 2002, Small and Pringle 2010) and experimentally enriched streams (Cross et al. 2003). In studies of natural $\mathrm{P}$ gradients in Costa Rican streams, many detritus-processing variables adhere to Michaelis-Menten P saturation kinetics at $\sim 25$ to $50 \mu \mathrm{g}$ SRP/L (Rosemond et al. 2002, Ramírez et al. 2003, Small and Pringle 2010). We observed a linear rather than a saturating relationship between litter $\mathrm{C}: \mathrm{P}$ and streamwater TP, probably because our sampling regime did not include enough stream sites with TP above the saturation concentration to confirm P saturation statistically.

We always sampled the Ozark streams in spring, $\sim 6$ mo after the autumn leaf fall. A key assumption when conducting leaf-litter enrichment experiments is the time required for microorganisms to induce chemical change in leaf litter. Ardón and Pringle (2007) reported an increase in respiration in response to $\mathrm{P}$ enrichment by the more labile Trema integerrima but not by the more recalcitrant Zygia longifolia leaves within a $16-\mathrm{d}$ period. This time might have been too short to capture a stoichiometric change in a recalcitrant leaf species. By the end of our laboratory experiment, higher-quality maple leaves had significantly greater \%P and lower C:P than the morerecalcitrant oak leaves. Michaelis-Menten kinetics on litter P:C in the laboratory experiment revealed that microbial activity stabilized the stoichiometric composition of leaves after $\sim 135$ and $32 \mathrm{~d}$ for maple and oak leaves, respectively.

Our experiment and survey were designed to demonstrate microbially mediated immobilization of $P$ from the water column. In some situations, leaf litter may be a net source of nutrients back into the water column (Webster et al. 2009). We acknowledge that laboratory studies may not extrapolate well to natural systems, but our results can be used to understand general trends in potential leaf-litter-associated microbial responses to varying water-column $\mathrm{P}$ concentrations. Further study is needed to refine our 
understanding of potential mechanisms involved that may cause variation in the microbial and stoichiometric response to enrichment.

\section{Conclusions}

That microbial activity can be enhanced by increasing nutrient availability is well known, but few investigators have looked quantitatively at the resulting elemental changes of the leaf litter, particularly with detailed time-series measurements. Increasing the availability of $\mathrm{P}$ increased leaf-litter quality by decreasing the C:P ratio. Our use of several $P$ concentrations in the laboratory and in the field survey may improve our understanding of possible threshold and saturating concentrations. We showed that the stoichiometric response of leaf litter depended on leaf species, level of $\mathrm{P}$ enrichment, and time in the stream. Furthermore, the dominant species of riparian cover may affect leaf-litter decomposition and $\mathrm{C}$ storage, potentially altering the trophic base of stream food webs. Understanding these quantitative links among riparian community structure, watercolumn P availability, and leaf-litter stoichiometry could inform management decisions for riparian zones and nutrient criteria in streams.

\section{Acknowledgements}

We thank Ayla Smartt, Erin Grantz, Brad Austin, and Hal Halvorson for their assistance with field and laboratory work. Funding for this research was provided by a grant from the National Science Foundation, Division of Environmental Biology (DEB-1020722). This manuscript was improved by the comments of 2 anonymous referees.

\section{Literature Cited}

Abelho, M., and M. A. S. GraçA. 2006. Effects of nutrient enrichment on decomposition and fungal colonization of sweet chestnut leaves in an Iberian stream (Central Portugal). Hydrobiologia 560:239-247.

AERTS, R. 1996. Nutrient resorption from senescing leaves of perennials: are there general patterns Journal of Ecology 84:597-608.

Alexander, R. B., R. A. Smith, G. E. Schwarz, E. W. Boyer, J. V. Nolan, and J. W. BRakebill. 2008. Differences in phosphorus and nitrogen delivery to the Gulf of Mexico from the Mississippi River Basin. Environmental Science and Technology 42:822-830.

APHA (American Public Health Association). 2007. Standard methods for the examination of water and wastewater. $21^{\text {st }}$ edition. American Public Health Association, American Water Works Association, and Water Pollution Control Federation, Washington, DC.
Ardón, M., And C. M. Pringle. 2007. The quality of organic matter mediates the response of heterotrophic biofilms to phosphorus enrichment of the water column and substratum. Freshwater Biology 52:1762-1772.

Baldy, V., V. Gobert, F. Guerold, E. Chauvet, D. Lambrigot, AND J. CHARCosset. 2007. Leaf litter breakdown budgets in streams of various trophic status: effects of dissolved inorganic nutrients on microorganisms and invertebrates. Freshwater Biology 52:1322-1335.

Benstead, J. P., L. Deegan, B. Peterson, A. Huryn, W. Bowden, K. Suberkropp, K. Buzby, A. Green, and J. Vacca. 2005. Responses of a beaded arctic stream to short-term $\mathrm{N}$ and P fertilisation. Freshwater Biology 50:277-290.

Brussock, P. P., A. V. Brown, And J. C. Dixon. 1985. Channel form and stream ecosystem models. Iournal of the American Water Resources Association 21:859-866.

Carpenter, S. R., N. F. Caraco, D. L. Correll, R. W. Howarth, A. N. Sharpley, AND V. H. Smith. 1998. Nonpoint pollution of surface waters with phosphorus and nitrogen. Ecological Applications 8:559-568.

Chadwick, M. A., AND A. D. Huryn. 2005. Response of stream macroinvertebrate production to atmospheric nitrogen deposition and channel drying. Limnology and Oceanography 50:228-236.

Cheever, B. M., E. B. Kratzer, and J. R. Webster. 2012. Immobilization and mineralization of $\mathrm{N}$ and $\mathrm{P}$ by heterotrophic microbes during leaf decomposition. Freshwater Science 31:133-147.

Cross, W. F., J. P. Benstead, A. D. Rosemond, and J. B. Wallace. 2003. Consumer-resource stoichiometry in detritus-based streams. Ecology Letters 6:721-732.

DodDs, W. K. 2003. Misuse of inorganic N and soluble reactive $\mathrm{P}$ concentrations to indicate nutrient status of surface waters. Freshwater Science 22:171-181.

DodDs, W. K. 2006. Eutrophication and trophic state in rivers and streams. Limnology and Oceanography 51:671-680.

DodDs, W. K. 2007. Trophic state, eutrophication and nutrient criteria in streams. Trends in Ecology and Evolution 22:669-676.

Dodds, W. K., W. W. Bouska, J. L. Eitzmann, T. J. Pilger, K. L. Pitts, A. J. Riley, J. T. Schloesser, and D. J. Thornbrugh. 2009. Eutrophication of U.S. freshwaters: analysis of potential economic damages. Environmental Science and Technology 43:12-19.

Elwood, J., J. Newbold, A. Trimble, and R. Stark. 1981. The limiting role of phosphorus in a woodland stream ecosystem: effects of P-enrichment on leaf decomposition and primary producers. Ecology 62:146-158.

Evans-White, M. A., W. K. Dodds, D. G. Huggins, and D. S. BAKER. 2009. Thresholds in macroinvertebrate biodiversity and stoichiometry across water-quality gradients in Central Plains (USA) streams. Iournal of the North American Benthological Society 28:855-868.

Evans-White, M. A., R. Stelzer, and G. Lamberti. 2005. Taxonomic and regional patterns in benthic macroinvertebrate elemental composition in streams. Freshwater Biology 50:1786-1799.

FINDLAY, S. 2010. Stream microbial ecology. Iournal of the North American Benthological Societv 29:170-181. 
FisHeR, S. G., AND G. E. LikENS. 1973. Energy flow in Bear Brook, New Hampshire: an integrative approach to stream ecosystem metabolism. Ecological Monographs 43:421-439.

Gessner, M. O., AND E. ChAuvet. 1994. Importance of stream microfungi in controlling breakdown rates of leaf-litter. Ecology 75:1807-1817.

Gessner, M. O., V. Gulis, K. A. Kuehn, E. Chauvet, and K. SuberKRopr. 2007. Fungal decomposers of plant litter in aquatic ecosystems. Pages 301-324 in I. S. Kubicek (editor). Environmental and microbial relationships. Springer, New York.

Greenwood, J. L., And A. D. Rosemond. 2005. Periphyton response to long-term nutrient enrichment in a shaded headwater stream. Iournal of Fisheries and Aquatic Sciences 62:2033-2045.

Greenwood, J. L., A. D. Rosemond, J. B. Wallace, W. F. Cross, AND H. S. WEYERS. 2007. Nutrients stimulate leaf breakdown rates and detritivore biomass: bottom-up effects via heterotrophic pathways. Oecologia (Berlin) 151:637-649.

GuLIS, V., AND K. SUBERKROPP. 2003. Leaf litter decomposition and microbial activity in nutrient-enriched and unaltered reaches of a headwater stream. Freshwater Biology 48:123-134.

Hill, W. R., F. H. McCormick, B. C. Harvey, S. L. Johnson, M. L. Warren, AND C. M. Elonen. 2010. Microbial enzyme activity, nutrient uptake and nutrient limitation in forested streams. Freshwater Biology 55:1005-1019.

Hill, W. R., B. J. Roberts, S. N. Francoeur, and S. E. Fanta. 2011. Resource synergy in stream periphyton communities. Journal of Ecology 99:454-463.

Hladyz, S., M. O. Gessner, P. S. Giller, J. Pozo, And G. WoODWARD. 2009. Resource quality and stoichiometric constraints on stream ecosystem functioning. Freshwater Biologv 54:957-970.

HowARTH, R. W., AND S. G. Fisher. 1976. Carbon, nitrogen, and phosphorus dynamics during leaf decay in nutrient-enriched stream microecosystems. Freshwater Biology 6:221-228.

Jarvie, H. P., P. J. A. Withers, M. J. Bowes, E. J. PalmerFelgate, D. M. Harper, K. Wasiak, P. Wasiak, R. A. Hodgkinson, A. Bates, C. Stoate, M. Neal, H. D. Wickham, S. A. HARMAn, And L. K. Armstrong. 2010. Streamwater phosphorus and nitrogen across a gradient in rural-agricultural land use intensity. Agriculture, Ecosvstems, and Environment 135:238-252.

KaushiK, N. K., And H. B. N. Hynes. 1971. The fate of the dead leaves that fall into streams. Archiv für Hydrobiologie 68:465-515.

Kobe, R. K., C. A. LepczyK, And M. Iyer. 2005. Resorption efficiency decreases with increasing green leaf nutrients in a global data set. Ecology 86:2780-2792.

Melillo, J. M., J. D. Aber, AND J. F. Muratore. 1982. Nitrogen and lignin control of hardwood leaf litter decomposition dynamics. Ecology 63:621-626.

Ramírez, A., C. M. Pringle, and L. Molina. 2003. Effects of stream phosphorus levels on microbial respiration. Freshwater Biology 48:88-97.

Robinson, C. T., AND M. O. Gessner. 2000. Leaf breakdown in an alpine spring brook. Verhandlungen der Internationalen Vereinigung für theoretische und angewandte Limnologie 27:744-747.
Romani, A. M., H. Fischer, C. Mille-Lindblom, And L. J. TRANVIK. 2006. Interactions of bacteria and fungi on decomposing litter: differential extracellular enzyme activities. Ecology 87:2559-2569.

Rosemond, A. D., P. J. Mulholland, And J. W. Elwood. 1993. Top-down and bottom-up control of stream periphyton: effects of nutrients and herbivores. Ecology 74:1264-1280.

Rosemond, A. D., C. M. Pringle, A. Ramírez, M. J. Paul, AND J. MeYer. 2002. Landscape variation in phosphorus concentration and effects on detritus-based tropical streams. Limnology and Oceanography 47:278-289.

Small, G. E., AND C. M. Pringle. 2010. Deviation from strict homeostasis across multiple trophic levels in an invertebrate consumer assemblage exposed to high chronic phosphorus enrichment in a Neotropical stream. Oecologia (Berlin) 162:581-590.

Small, G. E., J. P. Wares, And C. M. Pringle. 2011. Differences in phosphorus demand among detritivorous chironomid larvae reflect intraspecific adaptations to differences in food stoichiometry across lowland tropical streams. Limnology and Oceanography 56:268-278.

Sмітн, V. H. 2003. Eutrophication of freshwater and coastal marine ecosystems: a global problem. Environmental Science and Pollution Research 10:126-139.

Smith, V. H., G. D. Tilman, and J. C. Nekola. 1999. Eutrophication: impacts of excess nutrient inputs on freshwater, marine, and terrestrial ecosystems. Environmental Pollution 100:179-196.

Stelzer, R. S., J. Heffernan, and G. E. Likens. 2003. The influence of dissolved nutrients and particulate organic matter quality on microbial respiration and biomass in a forest stream. Freshwater Biology 48:1925-1937.

Suberkropp, K. F. 1998. Effect of dissolved nutrients on two aquatic hyphomycetes growing on leaf litter. Mycological Research 102:998-1002.

Suberkropp, K. F., and E. Chauvet. 1995. Regulation of leaf breakdown by fungi in streams: influences of water chemistry. Ecology 76:1433-1445.

Suberkropp, K. F., V. Gulis, A. D. Rosemond, And J. P. BeNSTEAD. 2010. Ecosystem and physiological scales of microbial responses to nutrients in a detritus-based stream: results of a 5-year continuous enrichment. Limnology and Oceanography 55:149-160.

SuberKRopp, K. F., And M. J. KLuG. 1974. Decomposition of deciduous leaf litter in a woodland stream, I. A scanning electron microscopic study. Microbial Ecology 1:96-103.

Suberkropr, K. F., And M. J. KLUG. 1976. Fungi and bacteria associated with leaves during processing in a woodland stream. Ecology 57:707-719.

Vannote, R. L., G. W. Minshall, K. W. Cummins, J. R. Sedell, And C. E. CusHING. 1980. The river continuum concept. Canadian Iournal of Fisheries and Aquatic Sciences 37:130-137.

Webster, J. R., J. D. Newbold, S. A. Thomas, H. M. Valett, and P. J. Mulholland. 2009. Nutrient uptake and mineralization during leaf decay in streams - a model simulation. International Review of Hydrobiology 94:372-390.

Received: 25 December 2012 Accepted: 19 April 2013 